\title{
Intensive Cultural Resources Survey of the Brushy Creek Sewer Line Phase 3 Project in the City of Ingram, Kerr County, Texas
}

Christopher M. Shelton

Follow this and additional works at: https://scholarworks.sfasu.edu/ita

Part of the American Material Culture Commons, Archaeological Anthropology Commons, Environmental Studies Commons, Other American Studies Commons, Other Arts and Humanities Commons, Other History of Art, Architecture, and Archaeology Commons, and the United States History Commons

Tell us how this article helped you.

This Article is brought to you for free and open access by the Center for Regional Heritage Research at SFA ScholarWorks. It has been accepted for inclusion in Index of Texas Archaeology: Open Access Gray Literature from the Lone Star State by an authorized editor of SFA ScholarWorks. For more information, please contact cdsscholarworks@sfasu.edu. 
Intensive Cultural Resources Survey of the Brushy Creek Sewer Line Phase 3

Project in the City of Ingram, Kerr County, Texas

\section{Creative Commons License}

\section{(c) (1) \&}

This work is licensed under a Creative Commons Attribution-NonCommercial 4.0 International License 


\section{FINAL: INTENSIVE CULTURAL RESOURCES SURVEY OF THE BRUSHY CREEK SEWER LINE PHASE 3 PROJECT IN THE CITY OF INGRAM, KERR COUNTY, TEXAS}

TEXAS ANTIQUITIES PERMIT NO. 9243

MAY 2020

PREPARED FOR

The City of Ingram

PREPARED BY

SWCA Environmental Consultants 



\title{
FINAL: INTENSIVE CULTURAL RESOURCES SURVEY OF THE BRUSHY CREEK SEWER LINE PHASE 3 PROJECT IN THE CITY OF INGRAM, KERR COUNTY, TEXAS
}

\author{
Prepared for \\ The City of Ingram, Texas \\ 230 Highway 39 , \\ Ingram, Texas 78025 \\ Prepared by \\ Christopher M. Shelton, M.A \\ SWCA Environmental Consultants \\ 6200 UTSA Boulevard \\ Suite 102 \\ San Antonio, Texas 78249 \\ www.swca.com
}

Principal Investigator

Christopher Shelton, M.A.

Antiquities Code of Texas Permit No. 9243

SWCA Project No. 58725

SWCA Cultural Resources Report No. 20-121

May 2020 
This page intentionally left blank. 


\section{ABSTRACT}

On behalf of the City of Ingram, Texas, SWCA Environmental Consultants (SWCA) conducted an intensive cultural resources survey of the proposed Brushy Creek Sewer Line Project (Project) in Kerr County, Texas. The approximately 1-mile-long sewer main extension line is being developed by the City of Ingram, a political subdivision of the State of Texas; therefore, the Project requires compliance with the Antiquities Code of Texas (ACT). In addition, the Project will receive federal funds from the U.S. Department of Agriculture (USDA); therefore, the work was conducted to comply with requirements of Section 106 of the National Historic Preservation Act (NHPA). This cultural resources investigation was conducted under ACT Permit No. 9243.

The Project begins just south of Winona Street West and terminates just south of Highway 27. The Project Area includes the proposed linear alignment situated within a 25-foot-wide corridor and lies on undeveloped land. Proposed impacts are expected to include widespread surficial modifications with deeper impacts in location of sewer lines.

The cultural resources investigation consisted of a background and historical map review, followed by intensive pedestrian survey augmented by shovel testing conducted by SWCA archaeologists. SWCA's background review determined that there are no known cultural resources within the Project area. SWCA also reviewed a 0.5 -mile study area surrounding the proposed Project. This review determined there are a total of five previously conducted surveys and six previously recorded archaeological sites within 0.5 mile of the Project area. None of the six previously recorded sites have been recommended as eligible for listing on the National Register of Historic Places (NRHP). Additionally, no NRHP districts or properties, sites designated as State Antiquities Landmarks, historical markers, cemeteries, or local neighborhood surveys were identified within the Project area or the larger study area.

During field investigations conducted on February 4, 2019, SWCA conducted an intensive archaeological pedestrian survey augmented with shovel testing of the Project area. For linear projects, the Texas Historical Commission (THC)/Council of Texas Archaeologists (CTA) survey standards require a minimum of 16 shovel tests per mile with thorough documentation of all exceptions noted (e.g., disturbance, slope, and impervious surfaces). Based on these standards, SWCA exceeded the requirements by excavating a total of 34 shovel tests within the 1-mile Project area. No cultural materials were identified on the ground surface or within any of the shovel tests excavated within the Project area.

In accordance with the ACT and with Section 106 of the NHPA (36 Code of Federal Regulations [CFR] 800.4 (b)(1)), SWCA has made a reasonable and good faith effort to identify historic properties within the area of potential effects. SWCA recommends a finding of No Historic Properties Affected per 36 CFR 800. 5(b) and no further archaeological investigation of the current Project area is recommended. No artifacts or samples were collected during this survey. All survey-related documentation will be curated at the Center for Archaeological Research, University of Texas at San Antonio. 
Final: Intensive Cultural Resources Survey of the Brushy Creek Sewer Line Phase 3 Project in the City of Ingram, Kerr County, Texas

This page intentionally left blank. 


\section{CONTENTS}

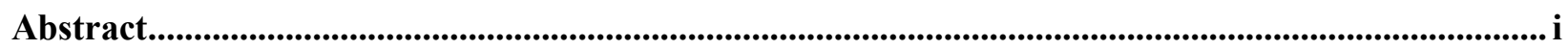

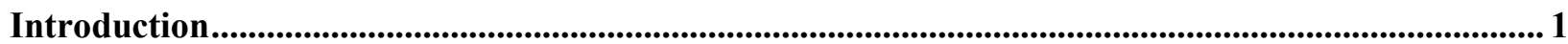

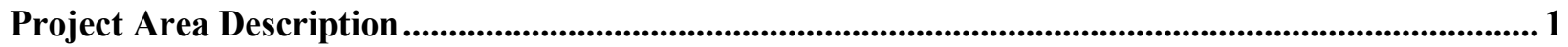

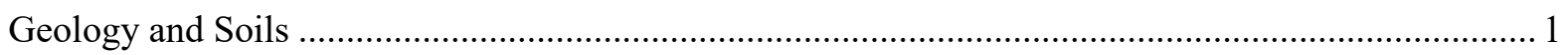

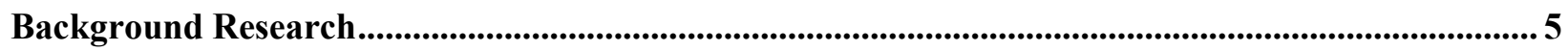

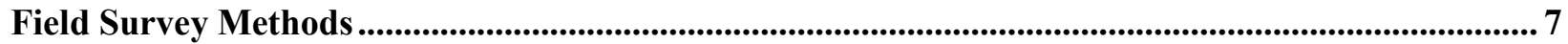

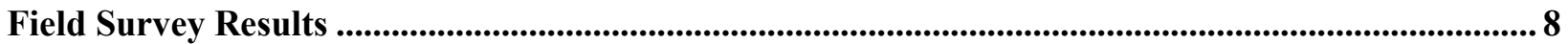

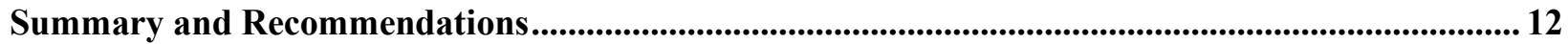

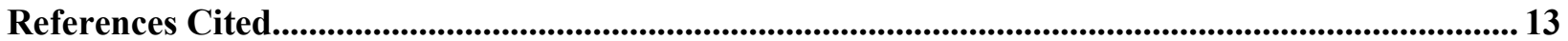

\section{Appendices}

APPENDIX A. Unanticipated Discoveries Plan

APPENDIX B. Shovel Test Log 


\section{Figures}

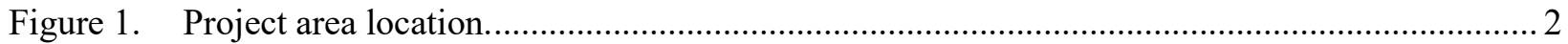

Figure 2. Project area on aerial imagery map.............................................................................. 3

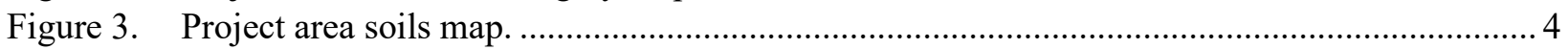

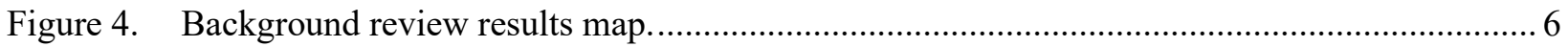

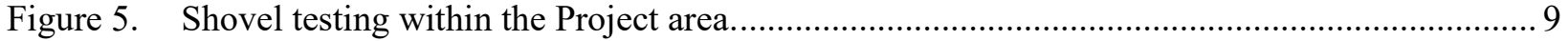

Figure 6. Typical vegetation within the Project area, facing north. .................................................... 10

Figure 7. Example of modern trash and vegetation debris within the Project area, facing west............ 10

Figure 8. Overview of Velma Street crossing the Project area, facing south...................................... 11

Figure 9. Shovel test LV02, an example of a typical shovel test within the Project area. .................... 11

\section{Tables}

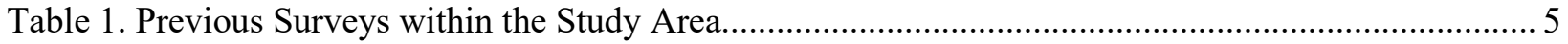




\section{INTRODUCTION}

On behalf of the City of Ingram in Kerr County, Texas, SWCA Environmental Consultants (SWCA) conducted an intensive cultural resources survey of the proposed Brushy Creek Sewer Line Phase 3 (Project) (Figure 1). The Project involves the construction and installation of an approximately 1-milelong sewer main extension line positioned within a 25-foot-wide corridor for an 8-inch pipe (Figure 2). As the Project is being developed by the City of Ingram (a subdivision of the State of Texas), the Project is subject to review under the Antiquities Code of Texas (ACT). In addition, the Project will receive federal funds from the U.S. Department of Agriculture (USDA); therefore, the work was conducted to comply with Section 106 of the National Historic Preservation Act (NHPA). The cultural resources investigation was conducted under ACT Permit No. 9243.

The goal of this investigation was to locate all prehistoric and historic cultural resources within the Project area, establish vertical and horizontal site boundaries, as appropriate, within the Project area, and evaluate the significance and eligibility of cultural resources for designation as State Antiquities Landmarks (SALs) and for the National Register of Historic Places (NRHP). This investigation complied with Secretary of Interior standards and followed the guidelines and procedures outlined in the Council of Texas Archeologists (CTA) standards for cultural resources investigations and the ACT, as outlined in the Texas Historical Commission's (THC's) Rules of Practice and Procedure for the Antiquities Code of Texas.

Chris Shelton, M.A., served as the Principal Investigator for the duration of the Project, overseeing overall logistics and organization, managing reporting, and agency consultation. SWCA archaeologists Laura Vilsack, M.A., and Jeromey Franklin, B.A., completed the archaeological survey on February 4, 2020. Jason Kainer and Liz Hitzfelder produced field and report maps for the Project, and Kelley Cox and Lauri Logan provided technical editing and document preparation.

\section{PROJECT AREA DESCRIPTION}

The approximately 1-mile-long Project area appears on portions of the Kerrville, Texas (3099-112) U.S. Geological Survey (USGS) 7.5-minute topographic quadrangle map (see Figure 1). The Project begins just south of Winona Street West within the Ingram city limits and terminates just south of Highway 27 (Figures 1 and 2). The Project Area includes the proposed linear alignment situated within a 25-foot-wide corridor and lies on undeveloped land. Proposed impacts within the survey corridor are expected to include widespread surficial modifications with deeper impacts in location of sewer lines (6 to 13.5 feet).

\section{Geology and Soils}

The underlying geology throughout the Project area consists of early Cretaceous-aged limestone deposits of the Glen Rose Formation (Barnes 1992). The Glen Rose formation consists primarily of limestone in a stairstep topography, with overlying sand and clay.

Soils mapped within the Project area include primarily the Krum silty clay, 3 to 5 percent slopes $(\mathrm{KrC})$ with the Kerrville clay loam, 1 to 8 percent slope $(\mathrm{KeD})$ positioned near the southern terminus. The Krum soils consist of very deep calcareous clayey alluvium sediments derived from interbedded chalk and marl and are found on level to moderately sloping treads of stream terraces on river valleys and dissected plains. The Kerrville clay loam consists of the Kerrville soil series and the Doss soil series, which are moderately deep Cretaceous-age indurated limestone that is weakly cemented. They are derived from Cretaceous age residuum and are found on the hill slopes, shoulders and summits of dissected plains (Figure 3; NRCS 2020). 
Final: Intensive Cultural Resources Survey of the Brushy Creek Sewer Line Phase 3 Project in the City of Ingram, Kerr County, Texas

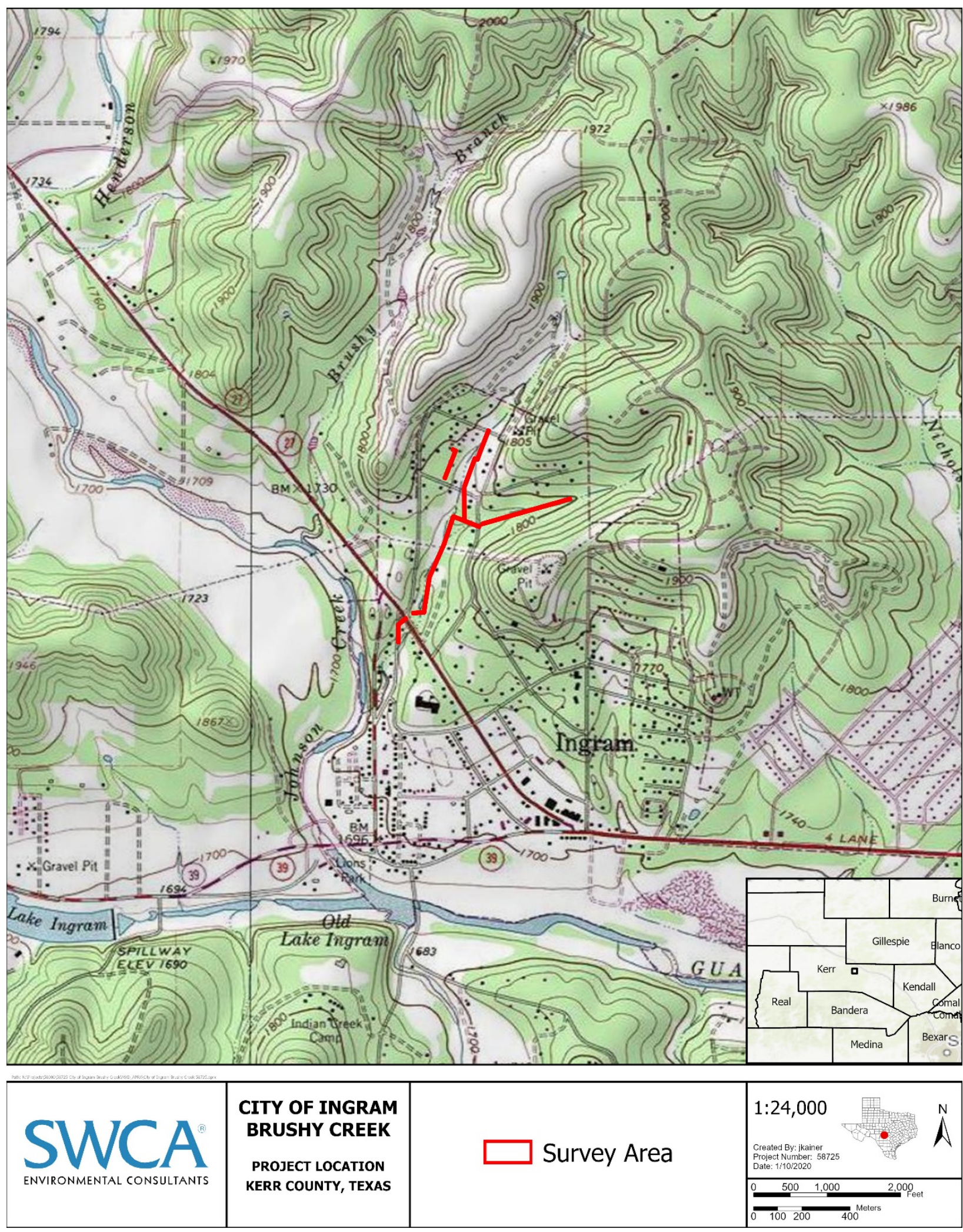

Figure 1. Project area location. 


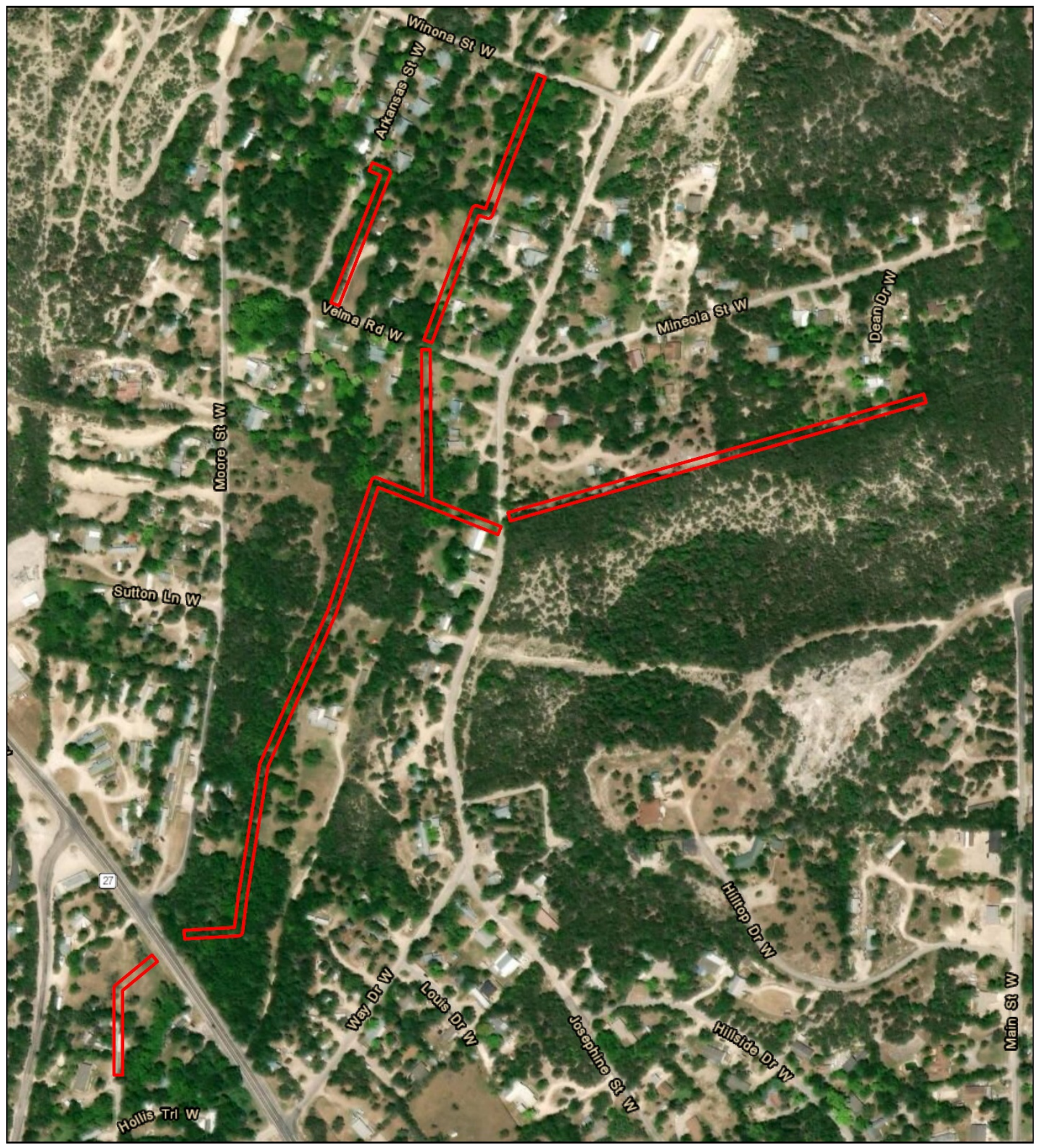

\begin{tabular}{|c|c|c|c|}
\hline & $\begin{array}{c}\text { CITY OF INGRAM } \\
\text { BRUSHY CREEK } \\
\text { AERIAL MAP }\end{array}$ & Survey Area & 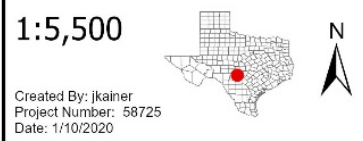 \\
\hline MENTAL & KERR COUNTY, TEXAS & & 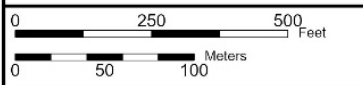 \\
\hline
\end{tabular}

Figure 2. Project area on aerial imagery map. 


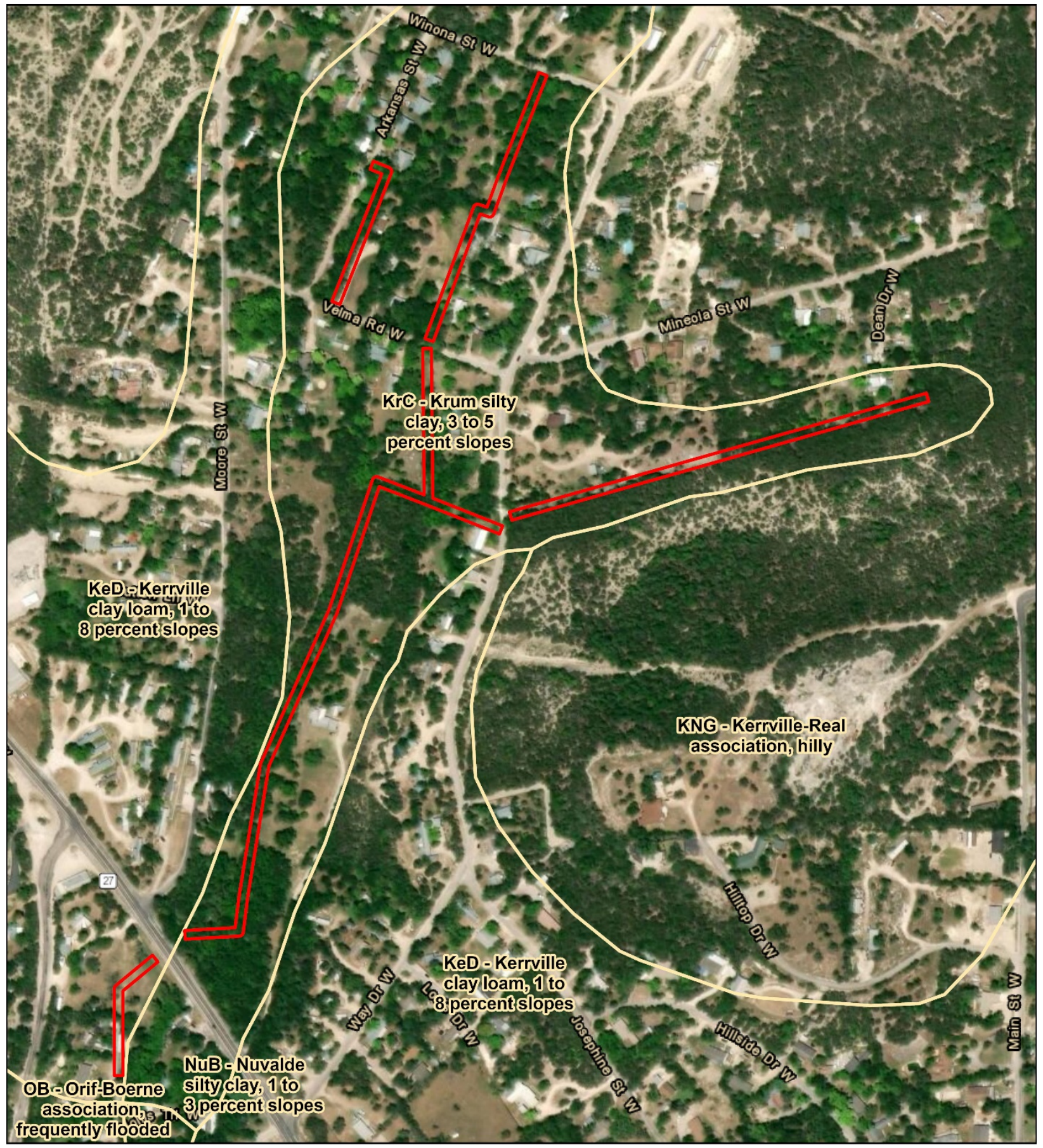

\begin{tabular}{|c|c|c|c|}
\hline 1 & $\begin{array}{c}\text { CITY OF INGRAM } \\
\text { BRUSHY CREEK } \\
\text { SOILS MAP }\end{array}$ & Survey Area & 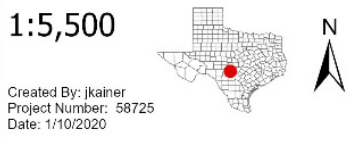 \\
\hline & KERR COUNTY, TEXAS & SUII UIII & $\overline{0} \frac{0}{50}{ }^{250} \overline{-100}^{\text {Meters }}{ }^{500}$ Feet \\
\hline
\end{tabular}

Figure 3. Project area soils map. 


\section{BACKGROUND RESEARCH}

On January 10, 2020, an SWCA archaeologist completed a desktop review of the Project. The review area includes an approximately 25 -foot-wide corridor Project area and an additional approximately 0.5 -milewide buffer area (i.e., study area) surrounding the Project alignment (Figure 4). The review used the Texas Archeological Sites Atlas (Atlas) online database (THC 2020) for previously conducted surveys and known sites within the review area. The review also consulted historical topographic maps available through the USGS Historical Topographic Map Explorer (USGS 2020), the Texas Historic Overlay (Foster et al. 2006), and modern aerial imagery to identify land use practices that may indicate the potential for or presence of cultural resources within the Project area.

The file search and literature review identified six previously recorded archeological sites and five previously conducted archaeological surveys within the study area, of which none are located within the Project area. No NRHP properties, SALs, Registered Texas Historic Landmarks, cemeteries, historic markers, or local neighborhood surveys were identified within either the Project or study areas.

Five previously conducted surveys (four areal and one linear) were identified within the study area. The previously conducted surveys were limited in the information provided on the THC sites Atlas regarding project details; see Table 1 for available details (THC 2020).

Table 1. Previous Surveys within the Study Area

\begin{tabular}{clcccc}
\hline Atlas Number & Project Type & $\begin{array}{c}\text { Date of } \\
\text { Survey }\end{array}$ & $\begin{array}{c}\text { ACT } \\
\text { Permit } \\
\text { No. }\end{array}$ & Sponsoring Agency & Invest. Firm \\
\hline 8500013530 & Areal survey & 2004 & 3325 & $\begin{array}{c}\text { Lower Colorado River Authority } \\
\text { (LCRA) }\end{array}$ & LCRA \\
\hline 8500016197 & Areal survey & 2009 & 4952 & Environmental Protection Agency & SWCA \\
\hline 8500021154 & Areal survey & 2012 & - & Texas Department of Transportation & TxDOT \\
\hline 8500028525 & Areal survey & 2013 & - & $\begin{array}{c}\text { Texas Water Development Board } \\
\text { (TWDB), City of Ingram }\end{array}$ & SWCA \\
\hline 8400004502 & Linear survey & 1988 & - & TWDB, EPA & -
\end{tabular}

Six previously recorded archaeological sites (i.e., 41KR245, 41KR620, 41KR624, 41KR31, 41KR32, and $41 \mathrm{KR} 91$ ) were identified within the study area of the proposed Project. One is multicomponent (i.e., 41KR620 [historic and prehistoric assemblages]) and five (i.e., 41KR624, 41KR245, 41KR31, 41KR32, and 41KR91) are prehistoric. Two of these sites have been determined Not Eligible for listing in the NRHP (i.e., 41KR620 and 41KR624), while four sites have no official determination and are therefore considered to have an undetermined eligibility. Two sites (i.e., 41KR31 and 41KR32) were also recommended for monitoring at the time of recordation.

41KR245 is recorded as an open campsite consisting of scattered burned rock, flakes, and cores. These materials were concentrated towards the eastern periphery of the site, along a fence line which bisects the site. All cultural materials were observed on the surface. At the time of recordation (1988), the investigating firm recommended avoidance and no SAL recommendation was provided. No further information was available on the THC sites Atlas regarding this site. 
Final: Intensive Cultural Resources Survey of the Brushy Creek Sewer Line Phase 3 Project in the City of Ingram, Kerr County, Texas

\title{
Restricted Information
}

\author{
Not for Public Disclosure
}

\section{Figure 4. Background review results map.}


Site 41KR620 is a multicomponent site which consisted of cultural material from both surface and subsurface contexts. The prehistoric component consisted of burned rock and a lithic scatter, as well as a few buried flakes. No evidence for cultural features was observed. The historic component consisted of tin cans, colorless glass shards, and blue-glazed earthenware observed on the surface. Dense vegetation covered most of the site and subsurface artifacts were considered out of context, due to root disturbances and the construction of the Ingram substation and Highway 27. These construction activities appear to have destroyed the integrity of the site. Site 41KR620 was determined Not Eligible for listing in the NRHP.

Site 41KR624 is a prehistoric site which consisted of surficial cultural materials only. The site was recorded as a lithic procurement site with flakes and widely scattered cores and core fragments. This site was thought to be continuous, measuring approximately 1,000 meters (m) in length. However, a twentieth century limestone quarry destroyed a portion of this site during the removal of an approximately $200 \mathrm{x}$ $200 \mathrm{~m}$ section of the ridgetop and subsequent site area. This quarry was noted as abandoned at the time of recordation. Site 41KR624 was determined Not Eligible for listing in the NRHP.

Sites 41KR31 and 41KR32 are both prehistoric sites which consist of diagnostic cultural materials. $41 \mathrm{KR} 31$ was originally recorded as a burned rock midden with chert, cores, flakes, and bifaces. The construction of a modern house was noted to have been erected in the center of the midden, near Johnson Creek at the time of recordation in 1970. During a 1997 revisit, the site had been bulldozed and the midden was not relocated; however, a concentration of fire-cracked rock (FCR) and a Montell preform were observed downslope, associating the site to the Late Archaic period. The landowner was preparing for the construction of a new house foundation in the location of the site, during which time monitoring of the construction activities was recommended. Site $41 \mathrm{KR} 31$ was destroyed after the construction of the home.

$41 \mathrm{KR} 32$ is described as a prehistoric open campsite or possible quarry dating roughly to the Middle Archaic period. Cultural materials were observed on the surface and consist of a Marshall dart point, flakes of all stages, tabular cobbles, sandstone mano fragment, bifaces, and the proximal end of a drill. The site had been disturbed during construction of a small dam and the removal of topsoil and caliche. Further investigation recommendations included monitoring during the 1997 investigation. No further information was available regarding this site.

Site 41KR91 is described as a large midden on the edge of a terrace near Johnson Creek. This site had been heavily vandalized (looted) at the time of recordation (1970) and was noted to be approximately 75 percent disturbed. Despite these disturbances, cultural materials were still visible on the surface and consisted of biface fragments, cores, a chopper fragment, and lithic flakes. No NRHP or SAL recommendations were made. No further information was available regarding this site on the THC sites Atlas.

\section{FIELD SURVEY METHODS}

The goal of the investigation was to locate all prehistoric and historic cultural resources within the Project area, establish vertical and horizontal site boundaries as appropriate within the Project area, and recommend NRHP and SAL eligibility of any cultural resources located within the Project area. This investigation followed the guidelines and procedures outlined in the CTA standards for cultural resources investigations and the ACT, as outlined in the THC's Rules of Practice and Procedure for the Antiquities Code of Texas. For linear projects, the THC/CTA survey standards require a minimum of 16 shovel tests per mile; SWCA exceeded the requirements by excavating a total of 34 shovel tests within the 1-mile- 
long Project area. Additional shovel testing would have been required to delineate cultural resources. Factors such as disturbances, site probability, and exposures would also affect shovel testing intensity.

The pedestrian survey was completed by qualified SWCA archaeologists who inspected the Project area using a single transect within the approximately 25 -foot-wide corridor to examine exposed ground surfaces for cultural material and above-ground features. The pedestrian survey was supplemented through manually excavated shovel tests placed at 50-m intervals along the proposed Project alignment. During the survey, archaeologists examined the ground surface for artifacts, features, and other prehistoric or historic material for proper documentation per state standards. Features of the landscape, such as depressions, ditches, mounds, and areas of differential vegetation, were also documented and inspected for cultural features.

Shovel tests were excavated in 20-centimeter arbitrary levels to a depth of $1 \mathrm{~m}$, unless soil conditions, Pleistocene-aged argillic horizons, or bedrock precluded reaching that depth. All matrix was screened through $1 / 4$-inch mesh for artifact recovery. SWCA plotted each shovel test using a sub-meter accurate global positioning system (GPS) receiver and recorded each test on appropriate project field forms. All surveyrelated documentation will be curated at the Center for Archaeological Research, University of Texas at San Antonio.

\section{FIELD SURVEY RESULTS}

On February 4, 2020, SWCA archaeologists conducted a 100 percent intensive archaeological pedestrian survey of the Project area, which is located along the northwestern margin of City of Ingram, Kerr County, Texas (Figure 5). The survey included visual and ground surface inspection augmented with shovel testing along a single transect within the Project area survey corridor and the inspection of any available surface exposures and erosional profiles.

Although the Project occurs within the Ingram city limits, the Project corridor consists largely of undeveloped land. Ground surface visibility varied greatly, ranging from 0 to 100 percent, but averaged near 0 percent across the Project due to the presence of tall grasses and leaf litter (Figure 6). The majority of the Project is located within a riparian wooded zone, as the alignment parallels two unnamed tributaries which feed into Johnson Creek, located approximately $280 \mathrm{~m}$ west of the southern terminus. The small strips of wooded lands are bounded on either side by residential developments. Modern trash and debris were observed over much of the surface throughout the Project area, although, no historic or prehistoric artifacts were encountered (Figure 7). Common disturbances within the Project area include roadways, powerline and telephone poles, as well as backyard improvements, such as gardens (Figure 8).

Subsurface examination of the Project area involved the excavation of 34 shovel tests throughout the Project area (i.e., JF01-JF14 and LV01-LV20) (Figure 5; Appendix B). Shovel tests typically contained very dark gray (10YR 3/1) to dark brown (10YR 3/3) clay loam with a moderate to high gravel/limestone content ranging from 5 percent to greater than 30 percent (Figure 9). Shovel tests extended to a maximum depth of approximately $65 \mathrm{~cm}$ below the surface $(\mathrm{cmbs})$ and terminated upon encountering impassable gravels, compact soils, or bedrock. No cultural materials were identified on the ground surface or within any of the shovel tests excavated within the Project area. 


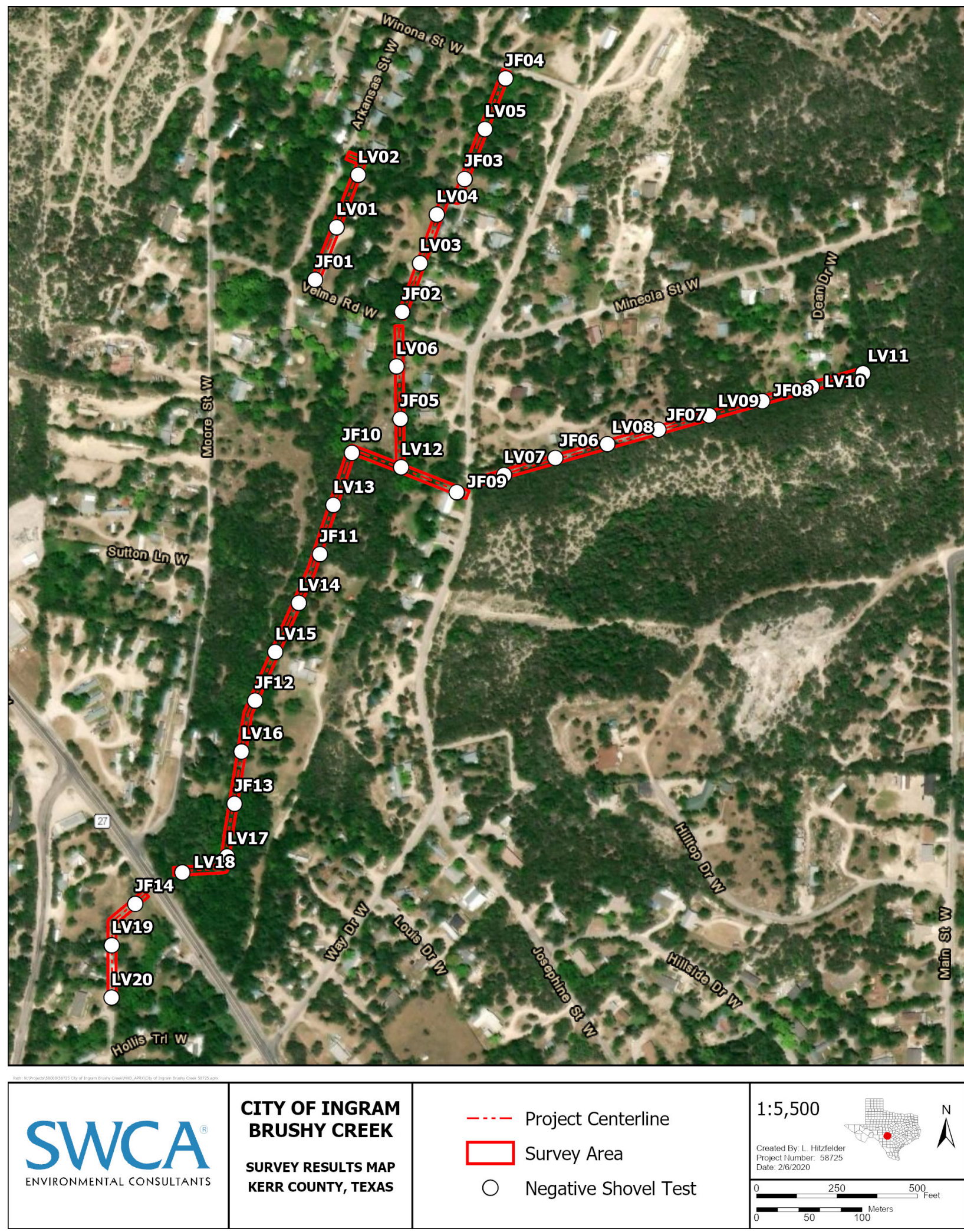

Figure 5. Shovel testing within the Project area. 


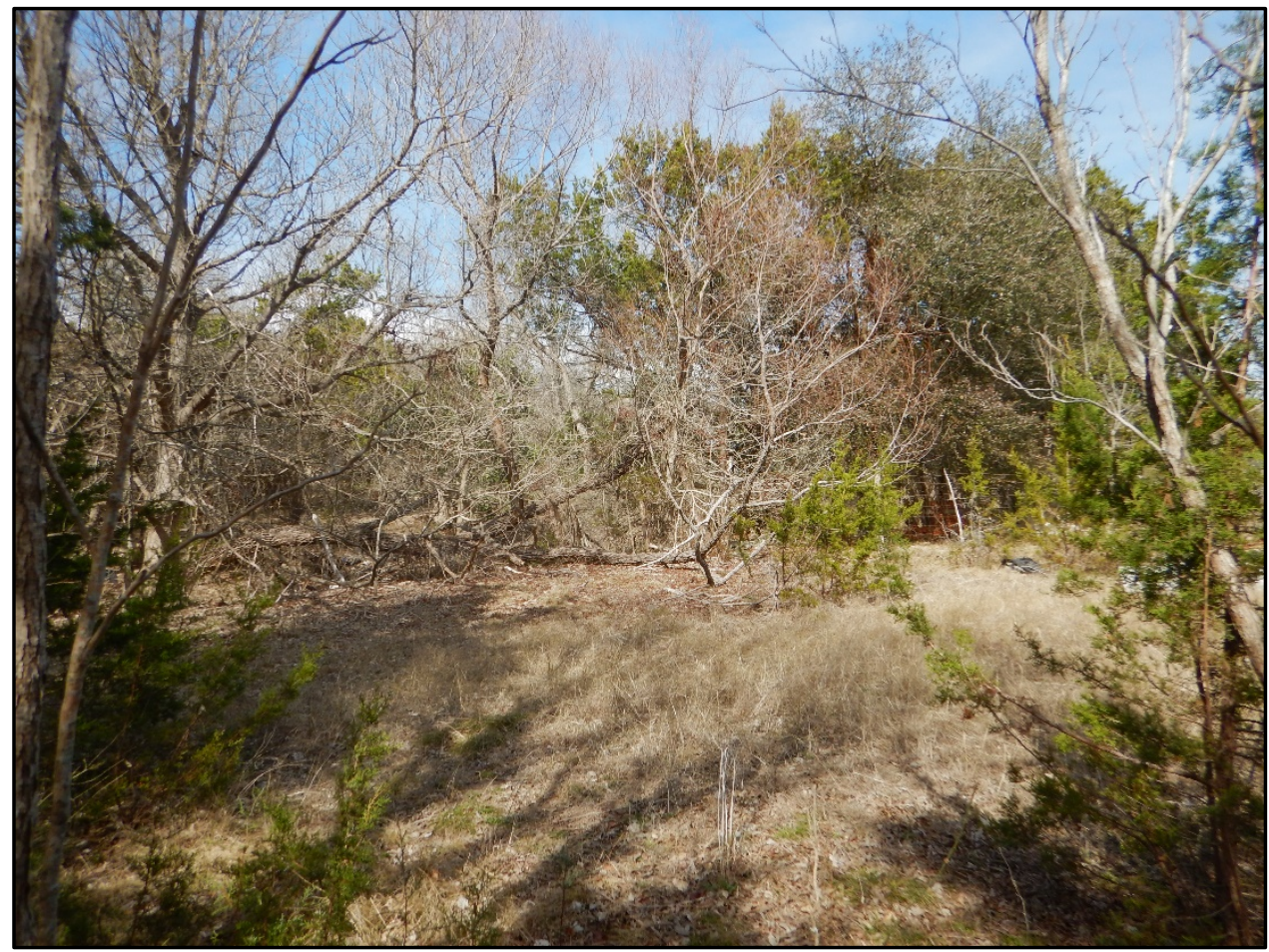

Figure 6. Typical vegetation within the Project area, facing north.

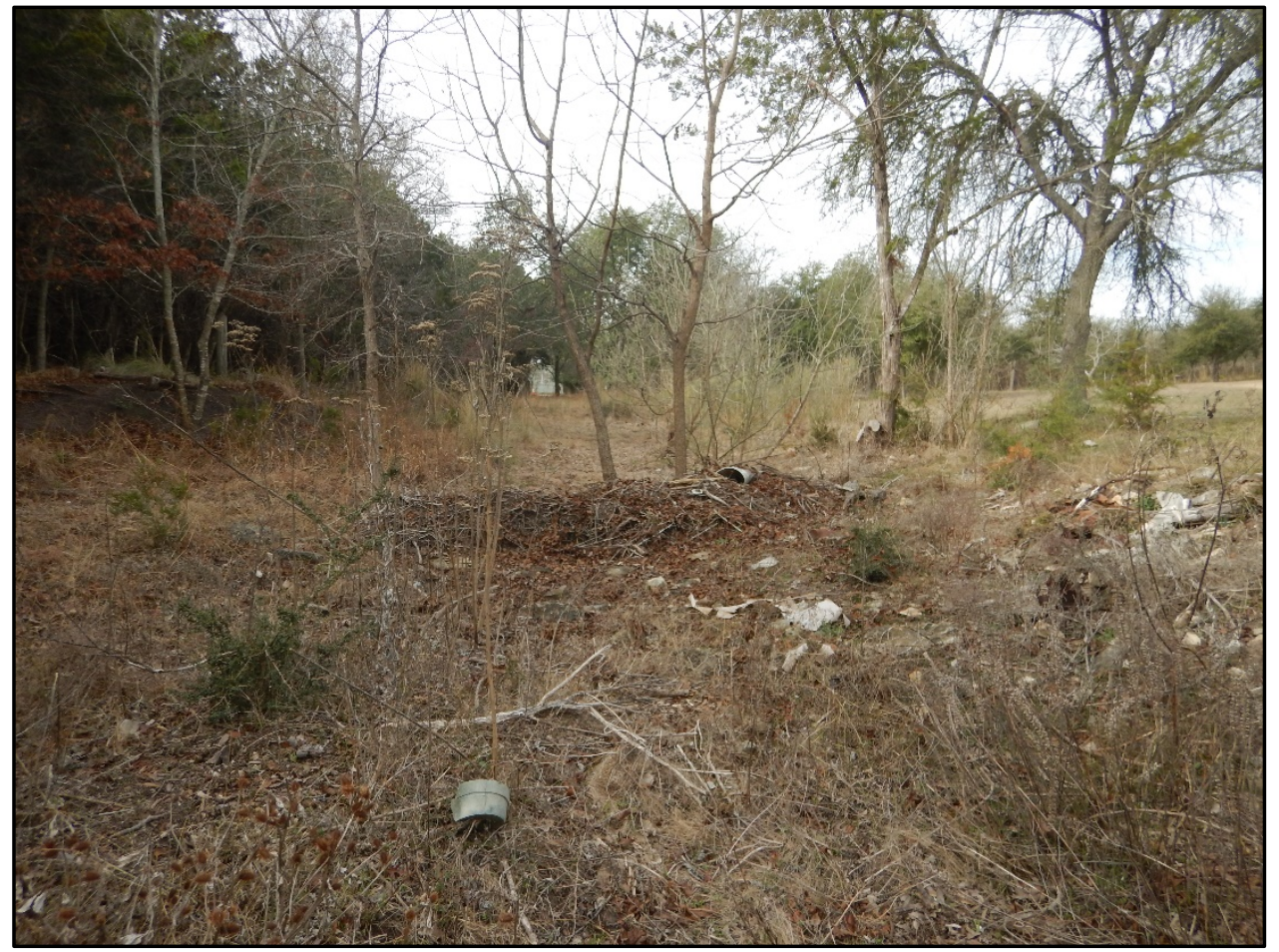

Figure 7. Example of modern trash and vegetation debris within the Project area, facing west. 
Final: Intensive Cultural Resources Survey of the Brushy Creek Sewer Line Phase 3 Project in the City of Ingram, Kerr County, Texas

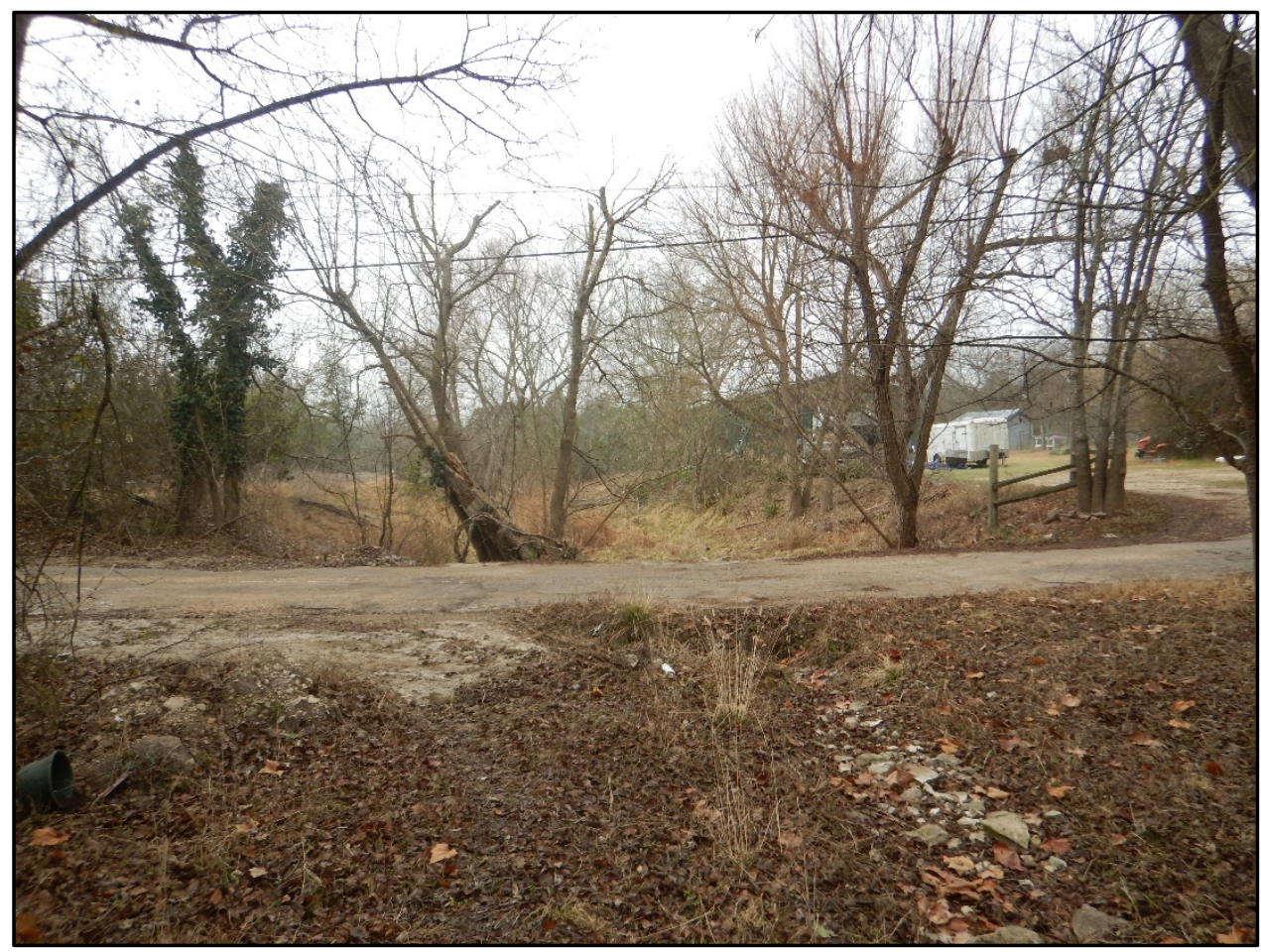

Figure 8. Overview of Velma Street crossing the Project area, facing south.

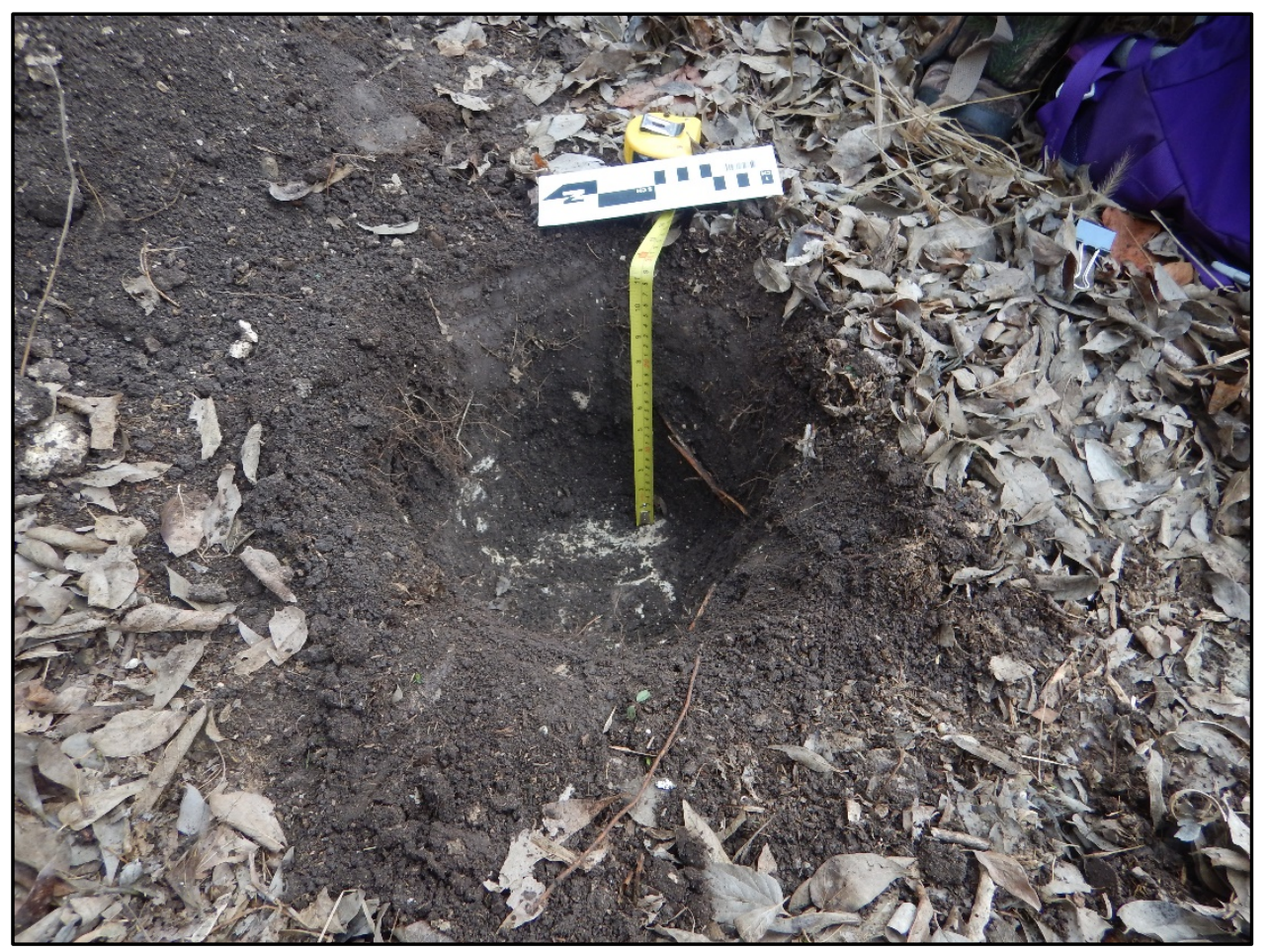

Figure 9. Shovel test LV02, an example of a typical shovel test within the Project area. 


\section{SUMMARY AND RECOMMENDATIONS}

On behalf of the City of Ingram, SWCA conducted an intensive cultural resources survey of the proposed 1-mile-long Brushy Creek Sewer Line Phase 3. The Project involves the construction and installation of an approximately 1-mile-long sewer main extension line positioned within a 25 -foot-wide corridor. As the Project is being developed by the City of Ingram (a subdivision of the State of Texas), the Project is subject to review under the ACT. In addition, the Project will receive federal funds from the USDA; therefore, the work was conducted to comply with Section 106 of the NHPA. The cultural resources investigation was conducted under ACT Permit No. 9243.

SWCA's background review determined that there are no known previously conducted cultural resources surveys or cultural resources within the Project area. A review of a 0.5 -mile-wide buffer area determined that there are five previously conducted archaeological surveys and six previously recorded archaeological sites. None of the six previously recorded sites have been recommended as eligible for listing on the NRHP. Additionally, no NRHP districts or properties, sites designated as SALs, historical markers, cemeteries, or local neighborhood surveys were identified within the Project area or the larger study area.

During field investigations on February 4, 2020, SWCA conducted an intensive archaeological pedestrian survey augmented with shovel testing of the Project area. For linear projects, the THC/CTA survey standards require a minimum of 16 shovel tests per mile with thorough documentation of all exceptions (e.g., disturbance, slope, and impervious surfaces). Based on these standards, SWCA exceeded the requirements by excavating a total of 34 shovel tests within the 1-mile-long Project area. No cultural materials were identified on the ground surface or within any of the shovel tests excavated within the Project area.

In accordance with 36 Code of Federal Regulations (CFR) 800.4(b)(1), as well as the ACT, SWCA has made a reasonable and good faith effort to identify cultural resources within the Project area. The archaeologists and architectural historian recommend a finding of No Historic Properties Affected per 36 CFR 800.4(d)(1). No further archaeological investigation of the current Project area is recommended. 


\section{REFERENCES CITED}

Barnes, Virgil E.

1992 Geological Atlas of Texas, San Antonio Sheet. Bureau of Economic Geology, The University of Texas at Austin.

Foster, T. R., T. Summerville, and T. Brown

2006 The Texas Historic Overlay: A Geographic Information System of Historic Map Images for Planning Transportation Projects in Texas. Prepared for the Texas Department of Transportation by PBS\&J, Austin, Texas.

Natural Resources Conservation Service (NRCS)

2020 Web Soil Survey. Available at: http://websoilsurvey.nrcs.usda.gov. Accessed February 2020.

Texas Historical Commission (THC)

2020 Texas Archeological Sites Atlas restricted database. Available at: http://pedernales.thc.state.tx.us/. Accessed February 2020.

U.S. Geological Survey (USGS)

2020 The National Geologic Map Database (TopoView). Historical topographic map collection. Available at: http://ngmdb.usgs.gov/maps/TopoView/. Accessed February 2020. 
Final: Intensive Cultural Resources Survey of the Brushy Creek Sewer Line Phase 3 Project in the City of Ingram, Kerr County, Texas

This page intentionally left blank. 


\section{APPENDIX A}

Unanticipated Discoveries Plan 
This page intentionally left blank. 
In the event of unexpected discovery of human remains or funerary objects/contexts during the survey, SWCA will comply with all applicable state laws (Texas Health and Safety Code Section 711 and the Texas Administrative Code Title 13, Chapter 22 Sections 22.1 through 22.6.), as well as taking into account the Advisory Council on Historic Preservation's 2007 Policy Statement on the Treatment of Burial Sites. Any human skeletal remains that may be discovered will, at all times, be treated with dignity and respect. If human remains are uncovered during investigations, the following steps will be taken:

- SWCA will halt excavation of the remains and shall notify the Kerr County sheriff and the THC. The sheriff will be requested to contact the coroner/medical examiner. After examining the human remains, if the sheriff and coroner determine the remains are modern then the sheriff or coroner will assume responsibility for the remains.

- Appropriate measures will be taken to ensure that the remains are protected and not disturbed prior to the conclusion of investigation by law enforcement and consultation with appropriate groups to determine next steps (if needed).

- Excavations (e.g., shovel testing) within 100 meters of the find will be halted until the THC authorizes continued work in those areas.

- Surveys will continue elsewhere in the Project area.

- If the county sheriff and coroner determine that the remains are not modern or a crime scene, thereby relinquishing their jurisdiction over the remains, SWCA will coordinate with the Project and THC to determine the appropriate course of action and file Notice of the Existence of a Cemetery. 
Final: Intensive Cultural Resources Survey of the Brushy Creek Sewer Line Phase 3 Project in the City of Ingram, Kerr County, Texas

This page intentionally left blank. 
Appendix B

Shovel Test Log 
This page intentionally left blank. 
Final: Intensive Cultural Resources Survey of the Brushy Creek Sewer Line Phase 3 Project in the City of Ingram, Kerr County, Texas

\begin{tabular}{|c|c|c|c|c|c|c|c|}
\hline ST \# & Level & $\begin{array}{l}\text { Depth } \\
\text { (cmbs) }\end{array}$ & $\begin{array}{c}\text { Munsell } \\
\text { Value }\end{array}$ & $\begin{array}{c}\text { Soil } \\
\text { Texture }\end{array}$ & Inclusions & $\begin{array}{l}\text { Negative/ } \\
\text { Positive }\end{array}$ & Comments \\
\hline LV01 & 1 & $0-5$ & $\begin{array}{l}\text { 10YR } 3 / 3 \\
\text { mixed with } \\
10 Y R \text { R/6 }\end{array}$ & silty loam & $70 \%$ pebbles & Negative & $\begin{array}{l}\text { Directly Adjacent to driveway (dirt). } \\
\text { Short grass with leaf debris. No } \\
\text { cultural material encounterd. } \\
\text { Terminated at bedrock. }\end{array}$ \\
\hline \multirow{2}{*}{ LV02 } & 1 & $0-15$ & 10YR 2/2 & loam & $\begin{array}{l}1 \% \text { roots, } 1 \% \\
\text { worms }\end{array}$ & Negative & No culturual material encountered. \\
\hline & 2 & $15-30$ & 10YR $8 / 2$ & limestone & $\begin{array}{l}80 \% \text { degrading } \\
\text { limestone }\end{array}$ & Negative & $\begin{array}{l}\text { GSV } 0 \% \text { due to leaf debris. No } \\
\text { culturual material encountered. } \\
\text { Terminated at bedrock. }\end{array}$ \\
\hline \multirow{2}{*}{ LV03 } & 1 & $0-30$ & 10YR 3/2 & Ioam & $\begin{array}{l}30 \% \text { degrading } \\
\text { limestone, } \\
\text { nodules } 2-3 \mathrm{~cm}, \\
1 \% \text { roots }\end{array}$ & Negative & No culturual material encountered. \\
\hline & 2 & $30-35$ & 10YR $8 / 2$ & Ioam & -- & Negative & $\begin{array}{c}\text { GSV } 50 \% \text { due to leaf fall; Directly } \\
\text { east of ditch/epherneral drainage. } \\
\text { No culturual material encountered. } \\
\text { Terminated at bedrock. }\end{array}$ \\
\hline \multirow[t]{2}{*}{ LV04 } & 1 & $0-40$ & 10YR $3 / 2$ & loam & $\begin{array}{l}5 \% \text { modern } \\
\text { trash, } 1 \% \\
\text { natural chert } \\
\text { cobbles, } 30 \% \\
\text { limestone } \\
\text { gravels, } 1 \% \\
\text { shells-helio }\end{array}$ & Negative & No culturual material encountered. \\
\hline & 2 & $40-50$ & 10YR 8/2 & loam & -- & Negative & $\begin{array}{c}\text { On slope towards drainage and } \\
\text { directly next to rooster cage. No } \\
\text { culturual material encountered. } \\
\text { Terminatd at bedrock }\end{array}$ \\
\hline \multirow[b]{2}{*}{ LV05 } & 1 & $0-45$ & 10YR 3/2 & clay loam & $1 \%$ roots & Negative & No culturual material encountered. \\
\hline & 2 & $45-65$ & 10YR $5 / 3$ & clay loam & $\begin{array}{l}40 \% \text { limestone } \\
\text { pebbles }\end{array}$ & Negative & $\begin{array}{l}\text { Modern day trash along surface. No } \\
\text { culturual material encountered. } \\
\text { Terminated at bedrock. }\end{array}$ \\
\hline LV06 & 1 & $0-10$ & 10YR 8/2 & silt & $80 \%$ limestone & Negative & $\begin{array}{l}\text { Directly east of drainage. No } \\
\text { culturual material encountered. } \\
\text { Terminated at bedrock. }\end{array}$ \\
\hline LV07 & 1 & $0-5$ & 10YR 2/1 & Loam & $\begin{array}{l}60 \% \text { limestone } \\
\text { gravels }\end{array}$ & Negative & $\begin{array}{c}\text { Shallow bedrock. No culturual } \\
\text { material encountered.Terminated at } \\
\text { bedrock. }\end{array}$ \\
\hline \multirow[b]{2}{*}{ LV08 } & 1 & $0-55$ & 10YR 2/1 & clay loam & $5 \%$ roots & Negative & No culturual material encountered. \\
\hline & 2 & $55-60$ & 10YR $5 / 3$ & clay loam & $\begin{array}{l}60 \% \text { limestone } \\
\text { gravels }\end{array}$ & Negative & $\begin{array}{l}\text { Large root system. No cultural } \\
\text { material encountered. Terminated at } \\
\text { root impasse. }\end{array}$ \\
\hline
\end{tabular}


Final: Intensive Cultural Resources Survey of the Brushy Creek Sewer Line Phase 3 Project in the City of Ingram, Kerr County, Texas

\begin{tabular}{|c|c|c|c|c|c|c|c|}
\hline ST \# & Level & $\begin{array}{l}\text { Depth } \\
\text { (cmbs) }\end{array}$ & $\begin{array}{l}\text { Munsell } \\
\text { Value }\end{array}$ & $\begin{array}{l}\text { Soil } \\
\text { Texture }\end{array}$ & Inclusions & $\begin{array}{l}\text { Negative/ } \\
\text { Positive }\end{array}$ & Comments \\
\hline LV09 & 1 & $0-60$ & 10YR 3/1 & clay loam & $\begin{array}{l}25 \% \text { limestone } \\
\text { gravels }\end{array}$ & Negative & $\begin{array}{l}\text { Chert observed on surface (not } \\
\text { cultural). No culturual material } \\
\text { encountered. Terminated at } \\
\text { compact sediment. }\end{array}$ \\
\hline LV10 & 1 & $0-30$ & $\begin{array}{l}\text { 10YR } 4 / 2 \text { to } \\
\text { 10YR } 6 / 4\end{array}$ & loamy silt & $\begin{array}{l}80 \% \text { gravels, } \\
\text { cobbles, } \\
\text { pebbles and } \\
\text { modern trash } \\
\text { debris }\end{array}$ & Negative & $\begin{array}{l}\text { Disturbed stream deposits. No } \\
\text { culturual material encountered. } \\
\text { Terminated at disturbance. }\end{array}$ \\
\hline & 1 & $0-30$ & 10YR 4/2 & loam & $5 \%$ roots & Negative & No culturual material encountered. \\
\hline LV11 & 2 & $30-65$ & 10YR 5/2 & clay silt & $\begin{array}{l}10 \% \text { limestone } \\
\text { pebbles }\end{array}$ & Negative & $\begin{array}{l}\text { No culturual material encountered. } \\
\text { Terminated at root impasse. }\end{array}$ \\
\hline LV12 & 1 & $0-50$ & 10YR 2/1 & clay loam & $50 \%$ roots & Negative & $\begin{array}{l}\text { Offset } 4 \text { meters west due to a dense } \\
\text { thicket of briars and offset twice due } \\
\text { to roots. No culturual material } \\
\text { encountered. Terminated at root } \\
\text { impasse. }\end{array}$ \\
\hline \multirow{2}{*}{ LV13 } & 1 & $0-10$ & 10YR 2/1 & loam & $\begin{array}{l}5 \% \text { organics } \\
\text { (roots and } \\
\text { worms), } 5 \% \\
\text { limestone } \\
\text { gravels }\end{array}$ & Negative & No culturual material encountered. \\
\hline & 2 & $10-20$ & 10YR $5 / 3$ & clay loam & $\begin{array}{l}60 \% \text { limestone } \\
\text { gravels and } \\
\text { cobbles }\end{array}$ & Negative & $\begin{array}{l}\text { Directly east of creek/drainage. I } \\
\text { expeected this to be deep, it wasn't. } \\
\text { No culturual material encountered. } \\
\text { Terminated at bedrock. }\end{array}$ \\
\hline LV14 & 1 & $0-40$ & 10YR 3/1 & clay loam & $\begin{array}{l}30 \% \text { cobbles } \\
\text { and gravels }\end{array}$ & Negative & $\begin{array}{c}\text { Bredrock visible on ground surface } \\
\text { adjacent ot ST. No culturual material } \\
\text { encountered. Terminated at } \\
\text { bedrock. }\end{array}$ \\
\hline LV15 & 1 & $0-40$ & 10YR 3/1 & clay loam & $\begin{array}{l}30 \% \text { cobbles } \\
\text { and gravels }\end{array}$ & Negative & $\begin{array}{l}\text { No culturual material encountered. } \\
\text { Terminated at bedrock. }\end{array}$ \\
\hline LV16 & 1 & $0-45$ & 10YR 3/1 & clay loam & $\begin{array}{l}30 \% \text { cobbles } \\
\text { and gravels }\end{array}$ & Negative & $\begin{array}{l}\text { No culturual material encountered. } \\
\text { Terminated at bedrock. }\end{array}$ \\
\hline LV17 & 1 & $0-10$ & 10YR 3/1 & loam & $\begin{array}{l}80 \% \text { limestone } \\
\text { cobbles }\end{array}$ & Negative & $\begin{array}{l}\text { Bedrock visible on surface; Large } \\
\text { cobbles and boulders in vicinity. No } \\
\text { culturual material encountered. } \\
\text { Terminated at Bedrock. }\end{array}$ \\
\hline LV18 & 1 & $0-10$ & 10YR 3/1 & loam & $\begin{array}{l}80 \% \text { limestone } \\
\text { cobbles }\end{array}$ & Negative & $\begin{array}{l}\text { Appears to be a drainage/ } \\
\text { floodplain; Modern debris, large } \\
\text { cobbles and downed trees } \\
\text { everywhere. No culturual material } \\
\text { encountered. Terminated at } \\
\text { bedrock. }\end{array}$ \\
\hline
\end{tabular}


Final: Intensive Cultural Resources Survey of the Brushy Creek Sewer Line Phase 3 Project in the City of Ingram, Kerr County, Texas

\begin{tabular}{|c|c|c|c|c|c|c|c|}
\hline ST \# & Level & $\begin{array}{l}\text { Depth } \\
\text { (cmbs) }\end{array}$ & $\begin{array}{l}\text { Munsell } \\
\text { Value }\end{array}$ & $\begin{array}{c}\text { Soil } \\
\text { Texture }\end{array}$ & Inclusions & $\begin{array}{l}\text { Negative/ } \\
\text { Positive }\end{array}$ & Comments \\
\hline LV19 & 1 & $0-5$ & 10YR 5/3 & Ioam & $\begin{array}{l}90 \% \text { gravels, } \\
\text { pebbles and } \\
\text { limestone }\end{array}$ & Negative & $\begin{array}{c}\text { No culturual material encountered. } \\
\text { Terminated at bedrock. }\end{array}$ \\
\hline LV20 & 1 & $0-5$ & 10YR 5/3 & loam & $\begin{array}{l}90 \% \text { gravels, } \\
\text { pebbles and } \\
\text { limestone }\end{array}$ & Negative & $\begin{array}{c}\text { In between creek and road. No } \\
\text { culturual material encountered. } \\
\text { Terminated at bedrock. }\end{array}$ \\
\hline JF01 & 1 & $0-30$ & 10YR 3/3 & clay loam & $1-5 \%$ gravel & Negative & $\begin{array}{c}\text { Neighborhood. No culturual material } \\
\text { encountered. Terminated at } \\
\text { compact soil. }\end{array}$ \\
\hline JF02 & 1 & $0-30$ & 10YR 3/3 & clay loam & $5 \%$ roots & Negative & $\begin{array}{l}\text { No culturual material encountered. } \\
\text { Terminated at root impasse. }\end{array}$ \\
\hline JF03 & 1 & $0-35$ & 10YR 3/3 & clay loam & $5 \%$ gravel & Negative & $\begin{array}{l}\text { No culturual material encountered. } \\
\text { Terminated at compact soil. }\end{array}$ \\
\hline JF04 & 1 & $0-30$ & 10YR 5/2 & silty clay & $10 \%$ gravel & Negative & $\begin{array}{l}\text { No culturual material encountered. } \\
\text { Terminated at compact soil. }\end{array}$ \\
\hline JF05 & 1 & $0-25$ & 10YR 4/2 & clay loam & roots & Negative & $\begin{array}{l}\text { No culturual material encountered. } \\
\text { Terminated at root impasse. }\end{array}$ \\
\hline JF06 & 1 & $0-30$ & 10YR 3/3 & clay loam & $5 \%$ gravel & Negative & $\begin{array}{l}\text { No culturual material encountered. } \\
\text { Terminated at compact soil. }\end{array}$ \\
\hline JF07 & 1 & $0-35$ & 10YR 4/2 & clay loam & $5 \%$ gravel & Negative & $\begin{array}{l}\text { Natural chert scatter; No culturual } \\
\text { material encountered. Terminated } \\
\text { at compact soil. }\end{array}$ \\
\hline JF08 & 1 & $0-35$ & 10YR $3 / 3$ & clay loam & $\begin{array}{l}5 \% \text { gravel, } 5 \% \\
\text { roots }\end{array}$ & Negative & $\begin{array}{l}\text { No culturual material encountered. } \\
\text { Terminated at compact soil. }\end{array}$ \\
\hline JF09 & 1 & $0-30$ & 10YR 4/4 & Ioam & $5 \%$ roots & Negative & $\begin{array}{l}\text { No culturual material encountered. } \\
\text { Terminated at compact soil. }\end{array}$ \\
\hline JF10 & 1 & $0-30$ & 10YR $3 / 3$ & clay loam & $5-10 \%$ roots & Negative & $\begin{array}{l}\text { No culturual material encountered. } \\
\text { Terminated at root impasse. }\end{array}$ \\
\hline JF11 & 1 & $0-35$ & 10YR $3 / 3$ & clay loam & $5 \%$ gravel & Negative & $\begin{array}{l}\text { No culturual material encountered. } \\
\text { Terminated at compact soil. }\end{array}$ \\
\hline JF12 & 1 & $0-25$ & 10YR 4/4 & clay loam & $>20 \%$ gravel & Negative & $\begin{array}{l}\text { Scattered limestone cobbles. No } \\
\text { culturual material encountered. } \\
\text { Terminated at gravel impasse. }\end{array}$ \\
\hline JF13 & 1 & $0-40$ & 10YR 3/3 & clay loam & $1-5 \%$ roots & Negative & $\begin{array}{l}\text { No culturual material encountered. } \\
\text { Terminated at compact soil. }\end{array}$ \\
\hline JF14 & 1 & $0-30$ & 10YR 4/4 & clay loam & $10-15 \%$ gravel & Negative & $\begin{array}{l}\text { No culturual material encountered. } \\
\text { Terminated at gravel impasse. }\end{array}$ \\
\hline
\end{tabular}

